\title{
A comparative study of floor construction on sloping sites: an analysis of cumulative energy demand and greenhouse gas emissions
}

\author{
Grace Ding and Perry Forsythe \\ University of Technology Sydney, Australia
}

\begin{abstract}
In order to make environmentally aware decisions, there is growing interest in the comparative energy and greenhouse gas (GHG) performance of competing construction methods. Little research has been done concerning competing ground floor construction methods, especially given different site variables, such as slope and soil type. A life cycle assessment approach was adopted to analyse environmental impacts, including cumulative energy demand and GHG emissions for detached housing construction in Australia. Data was drawn from 24 case study housing projects, including 12 reinforced concrete and 12 suspended timber floor projects. The data presented in the paper compares cumulative energy demand, GHG and the constituent parts of competing construction methods. The findings indicate that the timber floors use/create significantly less cumulative energy demand and GHG emissions than concrete floorsapproximately 2.1 to 2.7 times less energy and 2.3 to 2.9 times less GHG. These findings are limited to the site slope and foundation soil types identified in the paper. The main application of the work is in guidance concerning the lowest environmental impact options for detached housing construction.
\end{abstract}

Keywords: Cumulative energy demand, greenhouse gas emissions, ground floor construction, life cycle assessment.

Submission type: Research article

\section{Introduction}

Much has been said about the importance of climate change and the effect that human development has on it (Stern, 2007). In this context, much has also been written on the resourcehungry nature of the construction industry and the burden it places on climate change (Metz, 2007). It is not surprising, therefore, that there is growing interest in the comparative credentials of competing construction methods and the materials that they enlist. Such comparison is not always straightforward, because in certain instances, competing methods offer different sustainability benefits that are hard to resolve. This is the case when comparing floor construction methods in the context of detached residential construction in Australia, especially where contending with the associated subfloor construction brought about by differing site slopes and differing foundation soils. The two main options in the Australian context include reinforced concrete raft slab construction and suspended timber floor construction.

Copyright: Construction Economics and Building 2016. (C) 2016 Grace Ding and Perry Forsythe. This is an Open Access article distributed under the terms of the Creative Commons Attribution 4.0 Unported (CC BY 4.0) License (https://creativecommons.org/licenses/by/4.0/), allowing third parties to copy and redistribute the material in any medium or format and to remix, transform, and build upon the material for any purpose, even commercially, provided the original work is properly cited and states its license.

Citation: Ding, G., and Forsythe, P. 2016. A comparative study of floor construction on sloping sites: an analysis of cumulative energy demand and greenhouse gas emissions, Construction Economics and Building, 16(1), 33-49. DOI: http://dx.doi.org/10.5130/AJCEB.v16i1.4813

Corresponding author: Grace Ding; Email - Grace.Ding@uts.edu.au

Publisher: University of Technology Sydney (UTS) ePress 
There are various types of raft slab construction defined in AS2870, and of these, 'waffle raft' construction (Standards Australia, 2011 p.33) was chosen as the main area of study, since it tends to use materials efficiently in achieving structural requirements and involves minimal variation to suit differing foundation conditions. The configuration includes a floor plate with relatively narrow edge and intermediate footing beams running in both length and breadth directions. These beams are formed between large, rectilinear polystyrene pods. Construction is typically undertaken on top of a level soil platform facilitated by 'cut and fill' bulk excavation. Retaining wall construction and associated drainage are structurally required to hold back the perimeter banks of the cut and fill excavation.

The suspended timber floor option is comparatively lightweight, with no bulk excavation involved and subsequently no significant change to the site topography. It has an open subfloor which typically involves treated timber poles or precast concrete stumps, set in plain concrete pad footings. The pad footings are spaced to support a defined bearer and joist grid layout. The platform construction typically uses long span bearers and joists made from engineered timber, softwood or hardwood sections, as determined by availability and market conditions. A structural sheet platform floor typically made from plywood or particleboard is fixed on top of the joists; other floor finishes (e.g. carpets) may be added later.

Environmental measurement has yet to be fully considered in the context of these respective construction methods. Concrete raft slabs provide considerable thermal mass, which is potentially useful in reducing operating energy once the building is occupied. However, a disadvantage is that the construction process requires significant excavation, including associated energy and emissions arising from the excavation process (Ding and Forsythe, 2013). In contrast, Mahapatra and Gustavsson (2008) cite the advantages of wood as being lighter, easier to work with, less complex and faster in production than the likes of concrete buildings. Wood also provides stored carbon and the construction process is likely to use less embodied energy and create fewer emissions (Carre, 2011; Ximenes, Robinson and Wright, 2006).

It is clear, therefore, that there is a need to help determine which of the two options offer the best environmental outcomes and under which site-specific circumstances these occur. For instance, it has been found that path dependency within the construction industry often creates resistance to change concerning construction methods, and there may be a need to break this dependency if sustainability is to have a stronger role in determining appropriate construction methods (Mahapatra and Gustavsson, 2008).

This research on comparing construction methods is also important because energy rating schemes and environmental assessments often do not take into account the full life cycle perspective of the construction involved. For instance so called sustainability reporting tools (SRTs) do not necessarily allow an appropriate degree of construction comparison given the broad range of issues they cover including energy, transport, water, materials, waste, land use, ecology, pollution, innovation and cultural issues. Ding (2008) states that the SRTs used in assessing environmental performance of buildings are largely applicable for the design stage of a building life cycle. Siew, Balatbat and Carmichael (2013) further compare the popular SRTs (e.g. BREAM, LEED and Green Star) and it is useful in analysing a number of other issues involved where they point out that at times, such tools carry a lack of attention to life cycle perspectives; they have deterministic scoring which is problematic because of the subjective criteria involved; they involve a lack of published reasoning behind the scores allocated for each criterion and there is a lack of consensus concerning the weighting of individual criteria. Clearly, the above creates issues concerning the validity of comparison and measurement methods. Such issues also reduce the ability to work at a more theoretically explanatory level of understanding. The life cycle assessment (LCA) methodology can assist because it offers a standardised method of implementation and well bounded units of measures that can be applied at different unit scales 
of construction such as assembly, element, system or entire building levels. There is a relatively high degree of objectivity, analysis and the ability to compare competing construction methods. Further, the resulting information can be useful as freestanding findings but can also be potentially plugged into the reporting regimes used by SRTs.

In order to help determine the best option from an environmental perspective, this research compares the credentials of contrasting concrete raft slab and suspended timber floor construction from a life cycle perspective. Twenty-four projects were selected in New South Wales (NSW), Australia for the study. This research is aimed at analysing and comparing two commonly used construction methods of floor construction on sloping sites in terms of cumulative energy demand and greenhouse gas (GHG) emissions. The paper begins with a literature review of features and environmental impacts of materials used in both construction methods. Based on the literature review a multiple case study methodology was developed to analyse environmental impacts of construction activities for these two methods. Finally, LCA was applied to analyse cumulative energy demand and GHG emissions to 24 detached dwellings over a service life-span of 60 years.

\section{Material features of wood and concrete from an emission perspective}

Kauppi and Sedjo (2001) chart the potential role of forestation and wood products, with a view to managing carbon pools within global ecosystems around the world. Many sources assert that wood can significantly reduce $\mathrm{CO}_{2}$ emissions relative to other materials. Reasons include the way that dried wood products consist of $50 \%$ carbon drawn from $\mathrm{CO}_{2}$ removed from the atmosphere by growing trees. Wood is also said to consume less fossil fuel in manufacture than most competing materials and provides biomass displacement (Sathre and O'Connor, 2010).

Buchanan and Levine (1999) show that converting wood to a construction material requires much lower process energy and results in lower carbon emissions than other materials - mainly compared to brick and aluminium, and to a lesser extent steel and concrete. Their results indicate that a $17 \%$ increase in wood usage in the New Zealand building industry could result in a $20 \%$ reduction in carbon emissions from the manufacture of all building materials. In a similar study, Upton et al. (2008) found that net GHG emissions associated with wood-based houses in the US are $20-50 \%$ lower than emissions associated with thermally similar steel or concrete-based houses.

In the United States, the Consortium for Research on Renewable Industrial Materials collected life cycle inventory (LCI) and life cycle assessment (LCA) data on common structural wood products used in residential construction under a cradle-to-gate approach, as applied to two house designs and as detailed further by Perez-Garcia et al. (2005) and Lippke et al. (2004). Puettmann and Wilson (2005) built on this work and found that 33\% of the energy consumption for producing each wood product comes from renewable resources when the system boundaries consider forest regeneration and harvesting, wood products and resin production, and transportation life cycles.

Concrete offers quite a different profile to that of wood, with environmental origins in mineral extraction. As a manufactured material, one of its key constituent ingredients, cement, has not fared well in emissions studies. In 2001, cement was identified as contributing a significant 5\% to human-specific $\mathrm{CO}_{2}$ emissions globally (Worrell et al., 2001). In more recent years, blended cements have improved this situation considerably. Goggins, Keane and Kelly (2010) indicate that, while typical Portland cement-based concrete mixes contribute $68 \%$ of the total embodied energy in manufacturing concrete, alternative cements using ground granulated blast furnace slag reduce this component by $30 \%$. 
Concrete also relies on steel reinforcing for many structural applications - a material involving even higher embodied energy than concrete itself (Glover, White and Langrish, 2002). Temporary formwork and false-work also come as necessary parts of the construction system, and add to overall emissions from onsite processes. Further, the in situ nature of waffle raft slab construction (as studied in this research) limits the ability to maximize the environmental benefits associated with prefabrication. Lopez-Mesa et al. (2009) identified a 12.2\% lower impact from precast, relative to in situ, concrete construction.

\section{Applying the materials to specific construction methods and building typologies}

The respective contribution of embodied and operation energy to total energy is not always a fixed or straightforward relationship (Li, Zhu and Zhang, 2010). For instance, embodied energy is known to constitute a larger proportion in low energy buildings, which then enables delivery of improved operational performance (Thormark, 2002). Sartori and Hestnes (2007) found that embodied energy in low energy consumption buildings can vary between 9 and $46 \%$ of total energy, and that the embodied energy in conventional buildings can vary between 2 and 38\%. Carre (2011) found that the global warming impact of construction and materials contributed between 14 and $45 \%$, underpinning the relevance of this study in fleshing out greater detail about situational context and conditions.

In delving more deeply into specific timber and concrete construction methods, Gerilla, Teknomo and Hokao (2007) found that a steel reinforced concrete house had higher environmental impact than a wood house; and using only solar energy for the operation phase would reduce impact by $73 \%$ for the wooden house and $70 \%$ for the steel reinforced concrete house. Börjesson and Gustavsson (2000) studied the embodied energy in a multi-storey building, comparing wood to concrete framed construction, and their results are similar: that concreteframed buildings cause higher emissions than the equivalent wood building.

Gustavsson and Sathre (2006) tested the certainty of wood as a preferred environmental option relative to concrete by measuring changes in energy and $\mathrm{CO}_{2}$ balances caused by the variation of key parameters in the manufacture and use of the materials. They found the materials of the wood-framed building had lower energy and $\mathrm{CO}_{2}$ balances than those of the concrete-framed building in almost all cases, except where wood processing residue or demolition wood was not recovered and used as fuel.

Blengini and Di Carlo (2010) compared a low energy house design with the same design using minimum legal insulation requirements and found that even though the energy for heating was reduced by a ratio of 10:1, there was a significant contribution from construction materials especially the shell materials - and maintenance operations, to the point that the overall life cycle benefit of the low energy design was only reduced by 2.1:1 and the carbon footprint by 2.2:1 relative to the standard insulation requirements.

The main observation from the previous discussion is simply that there is significant variability between lightweight versus heavyweight construction and manifest differently according to different construction methods, climates and different phases over the life cycle of the building. This confirms the reason for undertaking the research detailed in this paper, especially in terms of the floor system and associated subfloor construction (including site slope and soil type) as relevant variables. Relatively little has been done with specific relevance to housing floor construction, where drawing on a sample of real world project designs can take into account site based variables. Inquiry into this relatively unstudied area is therefore the main contribution of this research. 


\section{Method}

The research adopts the LCA methodological approach to analyse environmental impacts for the study. LCA is a 'cradle-to-grave' approach and is a tool widely used for environmental performance evaluation (Khasreen, Banfill and Menzies, 2009). It is commonly used to analyse and assess the environmental performance of products, materials or processes over their life cycle in a comprehensive and systematic way. It considers impacts from the acquisition of raw materials to the final disposal of a project. In the 1990s, an environmental management standard was adopted by the International Organization for Standardization (ISO) as part of its 14000 Standards series (International Standards Organisation, 2006). In this series, the 14040 Standard focuses on establishing the principles and framework for LCA study (International Standards Organisation, 2006). The Standard states that the overarching aims of LCA include:

- Identification of purpose and boundary of the study, establishing the functional unit of analysis, and defining the key processes, material, and energy flows for analysis

- Collection of data and the analysis of material and energy flow for each stage of the product life cycle

- Use of inventory data to classify, aggregate, and characterize various midpoint and end point environmental impacts

- An interpretation of results and decision making

This research uses a case study approach to analyse and compare the environmental impact of ground floor construction using suspended timber and concrete raft slab on sloping sites of detached dwellings in NSW, Australia. The study focuses on the ground floor construction only as the construction of building elements above the ground floor slab are largely the same. It is typical building design for detached dwellings in Australia to use brick veneer structure where the external walls consist of a skin of brick on the outside and timber wall framing with plasterboard lining on the inside, with a cavity in between. Internal walls are timber stud with plasterboard lining on both sides, and roof to be timber with tile covering.

Given that the only variables for detached dwelling construction on sloping sites are the ground floor construction and the associated bulk excavation, the study scope was limited to ground floor construction in order to focus on the connection between the building and the ground. The choice to compare suspended timber and concrete raft floor construction methods was made in order to identify and quantify cumulative energy demand and associated GHG emissions in material manufacturing, construction and end-of-life processes for detached dwellings on sloping sites and hence to optimize the selection of design and construction methods from an energy consumption and GHG emissions perspective. The operating stage for detached dwellings is excluded from the study as virtually no maintenance will be required for the structure of the ground floor. Here, natural disasters such as bushfire and flood tend to be occurrences that are either hard to confidently predict or apply to specific geographic areas - hence making it inopportune to apply to the generalist scenarios explored in this study. In addition, timber componentry could be perceived as the most apparent material at maintenance risk - given the potential for termite and fungal attack - but there is little empirical evidence to support this where appropriately treated timber has been used (FWPA, 2010) and assuming professional attention to structural durability and drainage of moisture.

This project includes bulk cut and fill excavation on the formation of sloping sites for projects using concrete raft slab construction only, while detail excavation for footings is included for all the projects in both construction methods. The study also included construction of the entire ground floor and the associated footings and retaining structure for projects requiring a cut and fill process. Additionally, for the concrete raft slab option, the study included plant and 
equipment required for the onsite cut and fill excavation, as well as the initial production and subsequent use of materials needed for the construction of raft slab and retaining structure.

For the suspended timber floor option, the study focused on the construction of the timber floor, the associated structural components and concrete for pad footings. Only minor disruption of the natural ground and slope is usually required, since the floor is suspended from the natural ground. For both cases, full combustion of transportation of building materials to project sites and disposal of construction and demolition waste to landfill were included.

The system boundary was limited to the structure of the ground floor construction and the associated excavation for detached dwellings. The excavation and structure of retaining walls as required for the construction of concrete raft slabs were include in the analysis. The function unit defines the quantification of ground floor slab construction on sloping sites and the study includes all upstream and downstream emissions and waste in the construction of ground floor slabs for detached dwellings. The functional unit in the project has been defined as a detached residential dwelling with a life span of 60 years. The functional unit was set to $1 \mathrm{~m}^{2}$ of the dwelling (building) footprint which deals with the ground floor area of the building. The functional unit of the required retaining wall and associated subsoil drainage was set to $10 \mathrm{~m}^{2}$.

\section{Data collection}

\section{Case study projects}

Design document was obtained for 50 detached dwellings in NSW. A screening process of examining the location, slope, soil type, size, and construction details was developed. This screening process identified 24 projects that had similar layout and location. The 24 projects were divided into two groups and each group contained 12 projects.

The research used these two groups to assess and model cumulative energy demand and GHG emissions. The two groups are:

- Group A: 12 projects using reinforced concrete raft slab construction including cut and fill bulk excavation and related retaining wall construction for the footprint area of the dwelling;

- Group B: 12 projects using suspended timber floor construction built on top of the existing topography (i.e. no bulk excavation) and an open subfloor.

Table 1 summarizes details of these projects on a range of slopes and soil types. The table presents the information in both gross floor area (GFA) and building footprint (BF). GFA measures the sum of total floor area in a given project, while BF measures only the ground floor area. In Group A, projects ranged from 5-15 degrees, and Group B projects ranged from 6-16+ degrees. The upper end of both ranges represents steeply sloping sites. Soil types for each project were grouped using foundation categorization system in AS2870 (Standards Australia, 2011), which identifies the different types of clay and sandy soils that prevail in the areas under study. The type of soil affects the amount of work involved in excavation and concrete footing requirements.

Group A projects required levelling of the sloping ground using cut and fill excavation, but Group B projects did not require this treatment due to the much simpler pad footing system used. The table also shows that approximately $75 \%$ of projects in Group A were two-storey, compared with about $41 \%$ in Group B. On average, Group A projects have larger GFA and BF, amounting to $50 \%$ and $20 \%$ more respectively. 
Table 1: Summary of projects

\begin{tabular}{|c|c|c|c|c|c|c|c|c|c|c|}
\hline \multirow{2}{*}{$\begin{array}{l}\text { Project } \\
\text { Code }\end{array}$} & \multicolumn{2}{|c|}{$\begin{array}{c}\text { Gross Floor Area } \\
\left(\mathrm{m}^{2}\right)\end{array}$} & \multicolumn{2}{|c|}{ Building footprint $\left(\mathrm{m}^{2}\right)$} & \multicolumn{2}{|c|}{$\begin{array}{c}\text { Slope } \\
\text { (degree) }\end{array}$} & \multicolumn{2}{|c|}{ Levels } & \multicolumn{2}{|c|}{ Soil type } \\
\hline & $\mathbf{A}$ & B & $\mathbf{A}$ & B & $\mathbf{A}$ & $\mathbf{B}$ & $\mathbf{A}$ & $\mathbf{B}$ & $\mathbf{A}$ & B \\
\hline 1 & 228 & 127 & 228 & 127 & 5.36 & 6.06 & 1 & 1 & $\mathrm{M}$ & $\mathrm{M}$ \\
\hline 2 & 668 & 216 & 334 & 216 & 6.86 & 7.10 & 2 & 1 & $\mathrm{~S}$ & $\mathrm{M}$ \\
\hline 3 & 232 & 287 & 232 & 191 & 7.08 & 8.06 & 1 & 2 & $\mathrm{M}$ & $\mathrm{H}$ \\
\hline 4 & 216 & 271 & 216 & 154 & 7.10 & 9.32 & 1 & 2 & $\mathrm{M}$ & $\mathrm{M}$ \\
\hline 5 & 287 & 147 & 191 & 147 & 8.06 & 9.98 & 2 & 1 & $\mathrm{H}$ & $\mathrm{M}$ \\
\hline 6 & 271 & 295 & 154 & 171 & 9.32 & 10.32 & 2 & 2 & $\mathrm{M}$ & $\mathrm{M}$ \\
\hline 7 & 363 & 359 & 180 & 195 & 9.50 & 10.49 & 2 & 2 & $\mathrm{P}$ & $\mathrm{H}$ \\
\hline 8 & 295 & 189 & 171 & 91 & 10.32 & 10.73 & 2 & 2 & $\mathrm{M}$ & $\mathrm{M}$ \\
\hline 9 & 286 & 175 & 188 & 175 & 10.34 & 13.82 & 2 & 1 & $\mathrm{M}$ & M \\
\hline 10 & 359 & 155 & 194 & 155 & 10.49 & 15.09 & 2 & 1 & $\mathrm{H}$ & $\mathrm{M}$ \\
\hline 11 & 363 & 188 & 180 & 188 & 12.00 & 15.57 & 2 & 1 & $\mathrm{P}$ & $\mathrm{M}$ \\
\hline 12 & 380 & 220 & 171 & 220 & 15.00 & 16.42 & 2 & 1 & $\mathrm{P}$ & $\mathrm{M}$ \\
\hline Ave & 329 & 219 & 203 & 169 & - & - & - & - & - & - \\
\hline $\begin{array}{l}\text { Note: } \\
\text { M - Mode } \\
\text { H - Highly }\end{array}$ & $\begin{array}{l}\text { ely reac } \\
\text { eactive }\end{array}$ & . & & $\begin{array}{l}\text { tt clay or } \\
\text { shtly rea }\end{array}$ & $\begin{array}{l}\text { or loc } \\
\text { e clay }\end{array}$ & & & & & \\
\hline
\end{tabular}

Only detail construction drawings were provided. Therefore the initial task was to quantify all the materials and products used for the ground floor construction. An inventory dataset for the LCA study was developed. Table 2 summarises the inputs and outputs of materials for the projects. Construction details for the concrete raft slabs included three different types of retaining wall structure and subsoil drainage depending on site topography and soil types. The three types of retaining structure were treated timber $\log$ for relatively low slope sites, concrete block structure with concrete core fill and reinforced footings for poorer soil types and steeper slopes, and structural steel post with treated timber log infill for poorer soil strength such as sand and steeper slopes. Comparatively, suspended timber floor construction is simpler and no retaining wall structure is required. The only excavation required is for the pad footings for timber poles to support the floor framing.

Table 2: Inputs and outputs flows for the study

\begin{tabular}{|c|c|c|c|c|c|}
\hline \multicolumn{3}{|c|}{ Inputs } & \multicolumn{3}{|c|}{ Outputs } \\
\hline & Unit & Amount (Average) & & Unit & Amount \\
\hline \multicolumn{6}{|l|}{ Concrete raft floor construction } \\
\hline $\begin{array}{l}\text { Excavator on site for cut \& } \\
\text { fill activities }\end{array}$ & Litre/hr & $\begin{array}{l}15 \text { litre } / \text { hr } \\
\text { rate vary to soil \& } \\
\text { slope type) }\end{array}$ & $\begin{array}{l}\text { Levelled cut \& } \\
\text { fill platform }\end{array}$ & $\mathrm{m}^{2}$ & 1 \\
\hline $\begin{array}{l}\text { Truck remove excess } \\
\text { excavated materials to landfill } \\
\left(11 \mathrm{~m}^{3}\right) \text {, travel distance vary } \\
\text { from } 4 \text { to } 39 \mathrm{~km}\end{array}$ & Litre $/ \mathrm{km}$ & 40litres $/ 100 \mathrm{~km}$ & $\begin{array}{l}\text { RC slab and } \\
\text { beams }\end{array}$ & $\mathrm{m}^{3}$ & 1 \\
\hline Filling material & $\mathrm{m}^{3}$ & $\begin{array}{l}\text { Vary from } 10 \text { to } \\
123 \mathrm{~km}\end{array}$ & Retaining wall & $\mathrm{m}^{2}$ & 10 \\
\hline $\begin{array}{l}\text { Truck deliver filling material } \\
\text { to site }\left(11 \mathrm{~m}^{3}\right) \text {, travel distance } \\
\text { vary from } 6 \text { to } 36 \mathrm{~km}\end{array}$ & Litre $/ \mathrm{km}$ & 40litres/100km & Subsoil drainage & $\mathrm{m}^{2}$ & 10 \\
\hline $\begin{array}{l}\begin{array}{l}25 \mathrm{MPa} \\
\left(1 \mathrm{~m}^{3}\right)\end{array} \\
\mathrm{RC}\end{array}$ & & & $\begin{array}{l}\text { Cumulative } \\
\text { energy }\end{array}$ & $\mathrm{MJ} / \mathrm{m}^{2}$ & Various \\
\hline Cement & $\mathrm{kg}$ & 280 & GHG & $\begin{array}{l}\mathrm{kgCO} 2- \\
\mathrm{e} / \mathrm{m}^{2}\end{array}$ & Various \\
\hline
\end{tabular}




\begin{tabular}{|c|c|c|c|c|c|}
\hline \multicolumn{3}{|c|}{ Inputs } & \multicolumn{3}{|c|}{ Outputs } \\
\hline & Unit & Amount (Average) & & Unit & Amount \\
\hline Sand & $\mathrm{kg}$ & 685 & & & \\
\hline Aggregate & $\mathrm{kg}$ & 1,535 & & & \\
\hline Water & $\mathrm{kg}$ & 140 & & & \\
\hline Reinforcement & $\mathrm{kg}$ & 105 & & & \\
\hline Formwork & $\mathrm{kg}$ & 50 & & & \\
\hline Polystyrene & $\mathrm{kg}$ & 41 & & & \\
\hline \multicolumn{3}{|l|}{ Block retaining wall $\left(10 \mathrm{~m}^{2}\right)$} & & & \\
\hline Concrete block & $\mathrm{kg}$ & 2,808 & & & \\
\hline Cement & $\mathrm{kg}$ & 1,104 & & & \\
\hline Sand & $\mathrm{kg}$ & 2,747 & & & \\
\hline Aggregate & $\mathrm{kg}$ & 3,969 & & & \\
\hline Lime & $\mathrm{kg}$ & 92 & & & \\
\hline Steel & $\mathrm{kg}$ & 115 & & & \\
\hline Water & $\mathrm{kg}$ & 672 & & & \\
\hline \multicolumn{3}{|l|}{$\begin{array}{l}\text { Treated timber retaining wall } \\
\left(10 \mathrm{~m}^{2}\right)\end{array}$} & & & \\
\hline Treated timber & $\mathrm{kg}$ & 705 & & & \\
\hline Cement & $\mathrm{kg}$ & 269 & & & \\
\hline Sand & $\mathrm{kg}$ & 673 & & & \\
\hline Aggregate & $\mathrm{kg}$ & 1,279 & & & \\
\hline Blue metal & $\mathrm{kg}$ & 118 & & & \\
\hline Water & $\mathrm{kg}$ & 193 & & & \\
\hline \multicolumn{3}{|l|}{$\begin{array}{l}\text { Structural steel \& treated } \\
\text { timber retaining wall }\left(10 \mathrm{~m}^{2}\right)\end{array}$} & & & \\
\hline Steel & $\mathrm{kg}$ & 151 & & & \\
\hline Treated timber & $\mathrm{kg}$ & 276 & & & \\
\hline Cement & $\mathrm{kg}$ & 307 & & & \\
\hline Sand & $\mathrm{kg}$ & 769 & & & \\
\hline Aggregate & $\mathrm{kg}$ & 1,461 & & & \\
\hline Water & $\mathrm{kg}$ & 221 & & & \\
\hline \multicolumn{3}{|l|}{$\begin{array}{l}\text { Subsoil drainage (based on } \\
10 \mathrm{~m}^{2} \text { retaining wall) }\end{array}$} & & & \\
\hline PVC pipe & $\mathrm{kg}$ & 20 & & & \\
\hline Blue metal & $\mathrm{kg}$ & 4,054 & & & \\
\hline Geofabric & $\mathrm{kg}$ & 2 & & & \\
\hline \multicolumn{6}{|c|}{ Suspended timber floor construction } \\
\hline $\begin{array}{l}\text { Excavator on site for footing } \\
\text { excavation }\end{array}$ & Litre/hr & $\begin{array}{l}15 \text { litre } / \text { hr } \\
\text { rate vary to soil \& } \\
\text { slope type) }\end{array}$ & $\begin{array}{l}\text { Timber } \\
\text { suspended floor } \\
\text { and subfloor } \\
\text { framing }\end{array}$ & $\mathrm{m}^{3}$ & 1 \\
\hline $\begin{array}{l}\text { Truck remove excess } \\
\text { excavated materials to landfill } \\
\left(11 \mathrm{~m}^{3}\right), \text { travel distance vary } \\
\text { from } 8 \text { to } 39 \mathrm{~km}\end{array}$ & Litre $/ \mathrm{km}$ & 40litres/100km & $\begin{array}{l}\text { Cumulative } \\
\text { energy }\end{array}$ & $\mathrm{MJ} / \mathrm{m}^{2}$ & Various \\
\hline $\begin{array}{lll}\begin{array}{l}25 \mathrm{MPa} \\
\left(1 \mathrm{~m}^{3}\right)\end{array} & \text { Concrete footing } \\
\end{array}$ & & & GHG & $\begin{array}{l}\mathrm{kgCO} 2- \\
\mathrm{e} / \mathrm{m}^{2}\end{array}$ & Various \\
\hline Cement & $\mathrm{kg}$ & 280 & & & \\
\hline Sand & $\mathrm{kg}$ & 685 & & & \\
\hline Aggregate & $\mathrm{kg}$ & 1535 & & & \\
\hline Water & $\mathrm{kg}$ & 140 & & & \\
\hline \multicolumn{3}{|l|}{ Timber floor $\left(1 \mathrm{~m}^{2}\right)$} & & & \\
\hline Joists \& bearers & $\mathrm{kg}$ & 10 & & & \\
\hline Sub-floor framing & $\mathrm{kg}$ & 15 & & & \\
\hline Particleboard flooring & $\mathrm{kg}$ & 11 & & & \\
\hline Bolts & $\mathrm{kg}$ & 0.12 & & & \\
\hline
\end{tabular}




\section{Assessing cumulative energy demand and GHG emissions}

Inventory of material quantities were measured from the drawings. Once materials and energy were determined, a list of environmental profiles associated with each unit process was established using the GaBi 6 LCI database. In addition and as appropriate, other Government published literature was also used e.g. IPCC (2006), DCCEE (2010) and DEH (2006a; 2006b) publications.

Cumulative energy demand for the study was estimated in terms of primary energy consumption on a cradle-to-grave approach and is expressed as follows:

$$
\begin{aligned}
& \mathrm{LCE}=\mathrm{EE}_{i}+\mathrm{EE}_{r}+\mathrm{OE}+\mathrm{DE} \\
& \text { Where: } \\
& \mathrm{LCE}=\text { Life cycle energy } \\
& \mathrm{EE}_{i}=\text { Initial embodied energy } \\
& \mathrm{EE}_{r}=\text { Recurrent embodied energy during occupancy } \\
& \mathrm{OE}=\text { Operating energy } \\
& \mathrm{DE}=\text { Demolition energy }
\end{aligned}
$$

In addition to focusing on quantifying cumulative energy demand in terms of material and energy flows, Global Warming Potential (GWP) was also a key item measured from the project sample. GWP is commonly used to illustrate the climatic impact of different gases. The IPCC characterization factors are commonly used to assess the relative impact of different GHGs contributing to the problem of climate change. Generally, $\mathrm{CO}_{2}$ is adopted as the reference standard for GHG effects (IPCC 2006).

The GWP value was used to convert different types of gases into a carbon dioxide equivalent $\left(\mathrm{CO}_{2-\mathrm{e}}\right)$ for a 100-year time horizon. The metrics used for the assessment of GWP was expressed in the unit of kilograms of carbon dioxide equivalents per function unit $\left(\mathrm{kgCO}_{2-\mathrm{e}}\right)$. GHG were calculated purely with reference to $\mathrm{CO}_{2}, \mathrm{CH}_{4}$ and $\mathrm{N}_{2} \mathrm{O}$ because the remainder are seldom emitted in the construction process (Cole, 1998). Table 3 lists the GWP values of these GHGs.

Table 3: GWP of GHG emissions for the study

\begin{tabular}{|l|c|c|}
\hline \multicolumn{1}{|c|}{ Name } & Chemical formula & GWP for 100 years \\
\hline Carbon dioxide & $\mathrm{CO}_{2}$ & 1 \\
\hline Methane & $\mathrm{CH}_{4}$ & 25 \\
\hline Nitrous oxide & $\mathrm{N}_{2} \mathrm{O}$ & 298 \\
\hline Source: IPCC 2006 & \multicolumn{2}{|}{} \\
\hline
\end{tabular}

The cumulative energy demand and GHG emissions were quantified on a cradle-to-grave approach on the following parameters:

1. Initial embodied energy and associated GHG emissions for all the processes and materials pertaining to all the projects were calculated and multiplied with the energy intensity and GHG emission factors.

2. Energy consumption and GHG emissions for fuel combustion from transportation of materials to site, disposal of construction waste and disposal of demolition waste to landfill at the end of the building's life cycle.

3. Energy consumption and GHG emissions from plant and equipment for excavation during construction and demolition (including diesel fuel consumption for excavators and trucks). Total consumption was estimated by multiplying the predicted running time of the equipment by the average consumption of diesel fuel per unit of time. 
4. Maintenance and replacement as likely to be required to maintain the function of a building throughout its operational stage. However, for all projects, there is virtually no maintenance required if they are constructed to meet the previously defined Australian Standards. For instance, critical timber applications used for in-ground timber poles were treated to an 'H5' level of treatment which is capable of lasting the full service life of the building.

5. At the end of the building's life cycle, each house is assumed to be demolished and sent to landfill. There is potential recycling of materials such as steel, concrete and timber in the study. However the nature of what the reprocessing path, including the next life cycle of these materials is uncertain. Thus, no recycling was considered in the study in order to keep the system boundary as from cradle-to-grave. In the study, only the ground floor and retaining structure were assessed and proportioned.

\section{Data analysis and discussion}

\section{General overview}

Table 4 summarizes the cumulative energy demand and GHG emissions per GFA and BF in terms of megajoule $\left(\mathrm{MJ} / \mathrm{m}^{2}\right)$ and kilogram carbon dioxide equivalent $\left(\mathrm{kgCO}_{2-\mathrm{e}} / \mathrm{m}^{2}\right)$. Descriptive statistics were calculated to compare results for projects in both groups and results were presented in Table 4.

Table 4: Summary of results

\begin{tabular}{|c|c|c|c|c|c|c|c|c|}
\hline \multirow{3}{*}{$\begin{array}{l}\text { Project } \\
\text { Code }\end{array}$} & \multicolumn{4}{|c|}{ Group A Projects (RC) } & \multicolumn{4}{|c|}{ Group B Projects (Timber) } \\
\hline & \multicolumn{2}{|c|}{$\begin{array}{l}\text { Cumulative Energy } \\
\text { Demand }\left(\mathrm{MJ} / \mathrm{m}^{2}\right)\end{array}$} & \multicolumn{2}{|c|}{$\begin{array}{c}\text { GHG } \\
\text { Emissions } \\
\left(\mathrm{kgCO}_{2-\mathrm{e}} / \mathrm{m}^{2}\right)\end{array}$} & \multicolumn{2}{|c|}{$\begin{array}{l}\text { Cumulative Energy } \\
\text { Demand }\left(\mathrm{MJ} / \mathrm{m}^{2}\right)\end{array}$} & \multicolumn{2}{|c|}{$\begin{array}{c}\text { GHG } \\
\text { Emissions } \\
\left(\mathrm{kgCO}_{2-\mathrm{e}} / \mathrm{m}^{2}\right)\end{array}$} \\
\hline & GFA & BF & GFA & BF & GFA & BF & GFA & BF \\
\hline 1 & 1,292 & 1,292 & 151 & 151 & 562 & 562 & 49 & 49 \\
\hline 2 & 764 & 1,528 & 84 & 168 & 453 & 453 & 44 & 44 \\
\hline 3 & 815 & 815 & 95 & 95 & 272 & 409 & 27 & 40 \\
\hline 4 & 1,416 & 1,416 & 136 & 136 & 265 & 467 & 26 & 45 \\
\hline 5 & 1,006 & 1,512 & 104 & 157 & 611 & 611 & 61 & 61 \\
\hline 6 & 965 & 1,697 & 99 & 174 & 256 & 441 & 25 & 43 \\
\hline 7 & 744 & 1,501 & 85 & 172 & 226 & 416 & 21 & 39 \\
\hline 8 & 776 & 1,339 & 69 & 119 & 264 & 549 & 26 & 53 \\
\hline 9 & 995 & 1,514 & 102 & 155 & 599 & 599 & 53 & 53 \\
\hline 10 & 869 & 1,607 & 81 & 150 & 528 & 528 & 55 & 55 \\
\hline 11 & 456 & 919 & 53 & 107 & 476 & 476 & 49 & 49 \\
\hline 12 & 561 & 1,246 & 66 & 146 & 646 & 646 & 62 & 62 \\
\hline Mean & 888 & 1,366 & 94 & 144 & 430 & 513 & 41 & 49 \\
\hline Std. Dev. & 273 & 77 & 28 & 25 & 162 & 23 & 16 & 8 \\
\hline Range & 961 & 883 & 98 & 79 & 420 & 237 & 41 & 23 \\
\hline
\end{tabular}

The table presents the cumulative energy demand and GHG emissions per GFA and BF to facilitate comparison. GHG results for BF are typically higher compared to GFA because the former is only divided by the building footprint and not the total building area (as spread over multiple storeys). Using the $\mathrm{BF}$ unit helps highlight the fact that designing buildings to occupy small footprints will reduce energy and GHG emissions in concrete raft slab construction (compared to larger footprints), which means that multi-level design is relatively a better design for residential development on sloping sites. 
With regard to cumulative energy demand, concrete raft slabs on cut and fill platforms (Group A) have a wider range of 456 to 1,416 and 815 to $1,697 \mathrm{MJ} / \mathrm{m}^{2}$ respectively per GFA and BF. Comparatively, suspended timber floors (Group B) have a smaller range of 226 to 646 and 416 to $646 \mathrm{MJ} / \mathrm{m}^{2}$ respectively per GFA and BF. Concrete raft slabs consumed on average 888 and $1,366 \mathrm{MJ} / \mathrm{m}^{2}$ compared with projects using suspended timber floor of 430 and $513 \mathrm{MJ} / \mathrm{m}^{2}$ respectively per GFA and BF. Group B projects consumed approximately 2.1 and 2.7 times less energy than Group A projects respectively per GFA and BF.

In a similar way, GHG emissions of Group B projects exhibited better performance than Group A projects. Concrete raft slabs have a wider range of 53 to151 and 95 to $174 \mathrm{kgCO}_{2-\mathrm{e}} / \mathrm{m}^{2}$ as compared to suspended timber floors of 21 to 62 and 39 to $62 \mathrm{kgCO}_{2-\mathrm{e}} / \mathrm{m}^{2}$ respectively for GFA and BF. Group A emitted approximately 94 and $144 \mathrm{kgCO}_{2-\mathrm{e}} / \mathrm{m}^{2}$ compared with Group B projects, which emitted 41 and $49 \mathrm{kgCO}_{2-\mathrm{e}} / \mathrm{m}^{2}$. On average, the Group B projects emitted approximately 2.3 and 2.9 times less GHG than Group A projects respectively for GFA and BF.

Table 4 also calculates standard deviations for each project group. The figures in the table reveal that the dispersion of the data in Group B had less variability than the data in Group A for both cumulative energy demand and GHG emissions. Hence, concrete raft slab projects vary more within the features of the respective data sets, relative to the suspended timber floor projects.

Figures 1 and 2 compare cumulative energy demand and GHG emissions for both Group A and $\mathrm{B}$ projects per GFA and BF according to ascending slope. From the figures, Group B projects demonstrate less variance in both studies. Notwithstanding these differences, the gaps between Group A and B projects are still quite large, especially when presented per BF. This indicates that suspended timber floors perform relatively better than concrete raft slabs in terms of cumulative energy demand and GHG emissions for the range of slopes studied.
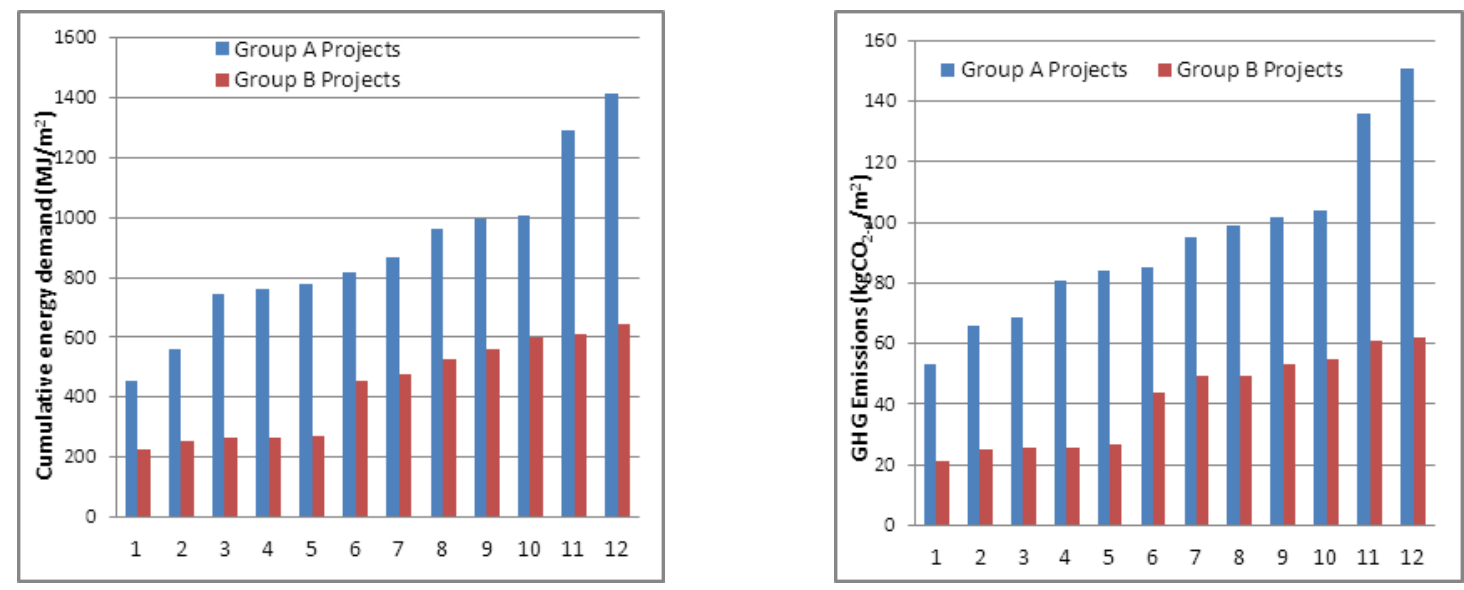

Figure 1: Cumulative energy demand and GHG emissions for both groups per GFA
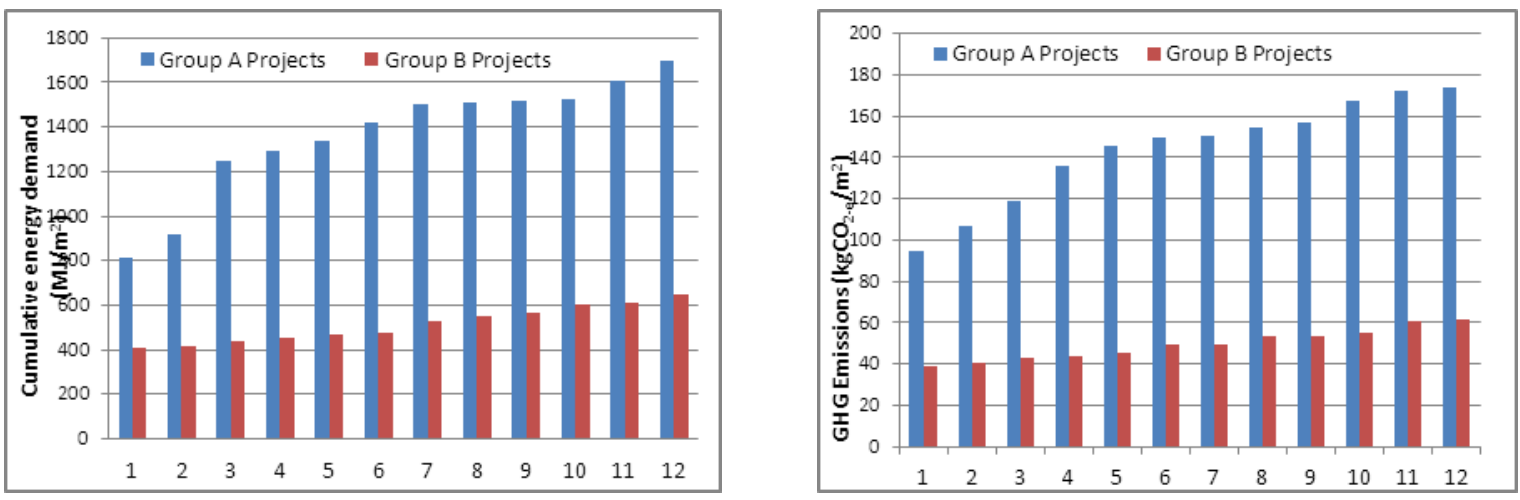

Figure 2: Cumulative energy demand and GHG emissions for both groups per BF 


\section{Analysis by major components}

Table 5 compares the average results of the main components for each construction system, using GFA and BF respectively. Further to the data shown in Table 5, Figures 3 and 4 present the constituent components in bar chart format. Specifically, the figures show the data as proportional component contributions to cumulative energy demand and GHG for projects of both groups. From these figures, it can more readily be seen that the main floor construction represents the major component for both Group A and B projects, which will dissected in greater detail under dedicated sub-headings.

Table 5: Summary of results by components

\begin{tabular}{|c|c|c|c|c|c|c|c|c|}
\hline \multirow{3}{*}{ Components } & \multicolumn{4}{|c|}{ Group A Projects (RC) } & \multicolumn{4}{|c|}{ Group B Projects (Timber) } \\
\hline & \multicolumn{2}{|c|}{$\begin{array}{l}\text { Cumulative energy } \\
\text { demand }\left(\mathrm{MJ} / \mathrm{m}^{2}\right)\end{array}$} & \multicolumn{2}{|c|}{$\begin{array}{c}\text { GHG } \\
\text { emissions } \\
\left(\mathrm{kgCO}_{2-\mathrm{e}} / \mathrm{m}^{2}\right) \\
\end{array}$} & \multicolumn{2}{|c|}{$\begin{array}{l}\text { Cumulative energy } \\
\text { demand }\left(\mathrm{MJ} / \mathrm{m}^{2}\right)\end{array}$} & \multicolumn{2}{|c|}{$\begin{array}{c}\text { GHG } \\
\text { emissions } \\
\left(\mathrm{kgCO}_{2-\mathrm{e}} / \mathrm{m}^{2}\right) \\
\end{array}$} \\
\hline & GFA & BF & GFA & BF & GFA & BF & GFA & BF \\
\hline $\begin{array}{l}\text { Cut and fill (include } \\
\text { subsoil drainage and } \\
\text { retaining walls) }\end{array}$ & 140 & 222 & 12 & 19 & - & - & - & - \\
\hline Footing excavation & - & - & - & - & 5 & 6 & 1 & 1 \\
\hline Ground floor structure & 727 & 1,111 & 80 & 122 & 413 & 492 & 40 & 48 \\
\hline End-of-life disposal & 21 & 33 & 2 & 2 & 12 & 15 & 1 & 1 \\
\hline Total & 888 & 1,366 & 94 & 143 & 430 & 513 & 42 & 50 \\
\hline
\end{tabular}

a) Cumulative energy demand

For cumulative energy demand, Table 5 and Figure 3 indicate that the main concrete raft slab construction was by far the main contributor for Group A projects, at $82 \%$ (equivalent to 727 and $1,111 \mathrm{MJ} / \mathrm{m}^{2}$ per GFA and BF respectively). This was followed by a $7 \%$ contribution from cut and fill excavation; retaining wall construction came next at $5 \%$; followed by subsoil drainage at $4 \%$ (a combine of 140 and $222 \mathrm{MJ} / \mathrm{m}^{2}$ per GFA and $\mathrm{BF}$ ); end of life processes only represented $2 \%\left(21\right.$ and $33 \mathrm{MJ} / \mathrm{m}^{2}$ per GFA and $\left.\mathrm{BF}\right)$.

For the concrete raft slab ancillary construction (C\&F, retaining wall and sub-soil drainage) is necessary for making the ground floor construction possible. In a combined sense, these ancillary works represent a total of $16 \%$ of cumulative energy demand. It is worthwhile considering this work as a collective sub-group, because it helps identify a systematic area that could be targeted for improvement in the overall environmental performance for concrete raft slab construction on sloping sites. The cut and fill processes (including subsoil drainage and retaining wall construction) - only applicable to concrete raft slab (Group A) - constitutes an additional 140 and $222 \mathrm{MJ} / \mathrm{m}^{2}$ of energy respectively for GFA and BF. For the cut and fill method, three types of retaining walls were involved to batter the soil for creating a level platform. Seven projects used treated timber logs, three used structural steel posts with treated $\log$ infill pieces, while two others used concrete block with concrete core fill and RC footings. Timber retaining walls consumed the least energy, approximately $756 \mathrm{MJ} / \mathrm{m}^{2}$, steel posts with timber infill consumed $1,028 \mathrm{MJ} / \mathrm{m}^{2}$, and concrete block consumed the most energy, at approximately $1,403 \mathrm{MJ} / \mathrm{m}^{2}$ of wall area.

For the suspended timber floor construction (Group B), the main floor structure contributed $83 \%$, and plain concrete pad footings add an extra $13 \%$. These two items make up $96 \%$ of the total and contribute approximately 413 and $492 \mathrm{MJ} / \mathrm{m}^{2}$ per GFA and BF, respectively. Given these results, it can be seen that the timber floor option does not involve any of the necessary ancillary works required for the concrete raft slab option. Only a minor amount of footing excavation is required, compared to that required for the cut and fill bulk excavation for the concrete option. Comparatively, the suspended timber floor method only requires approximately 
5 and $6 \mathrm{MJ} / \mathrm{m}^{2}$ respectively for GFA and BF for footing excavation for construction on sloping sites, while as per the previous discussion, the concrete option requires 140 and $222 \mathrm{MJ} / \mathrm{m}^{2}$ of energy respectively for GFA and BF. This and the impact of using reinforced concrete as the main construction material go some way to explaining the difference in the cumulative energy demand of the two options.

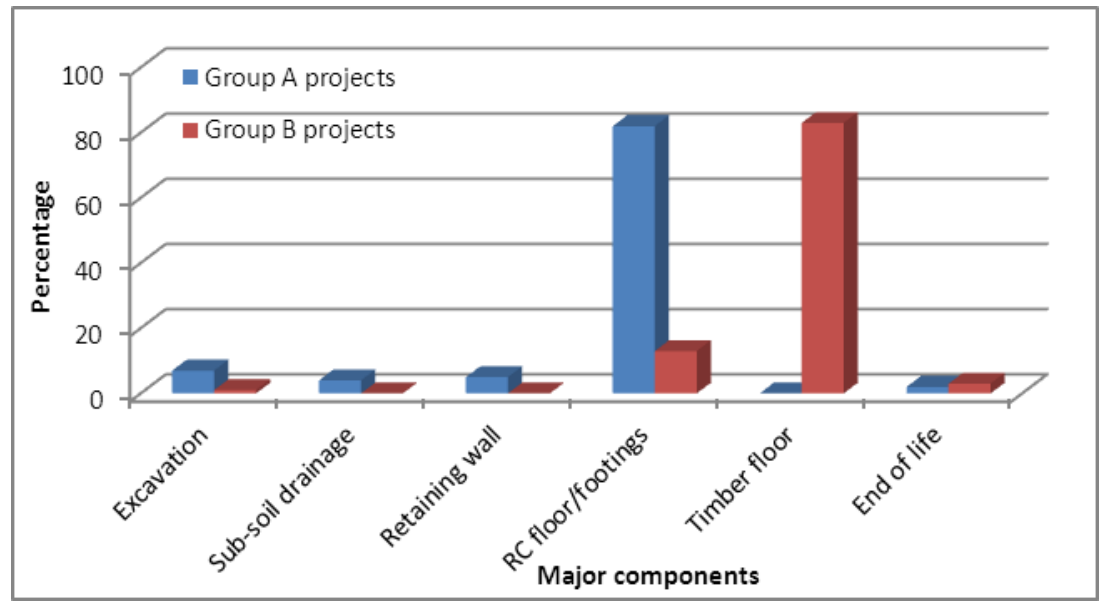

Figure 3: Cumulative energy demand by major components for both groups

This means that, if only comparing the main floor structures and excluding both ancillary works and end of life energy, it can be said that for GFA and BF, concrete raft slab construction has consumed 1.8 and 2.3 times more energy than suspended timber floor construction. It can also be said that as a generalization, end-of-life disposal of demolition waste was negligible in the study, only representing $2 \%$ and $3 \%$ respectively for concrete and timber construction options.

b) GHG emissions

The GHG emissions assessment follows a similar setting as the cumulative energy demand. In Figure 4 the two floor structures are still the major emitters of GHG, contributing approximately $85 \%$ and $97 \%$ respectively for concrete and timber construction.

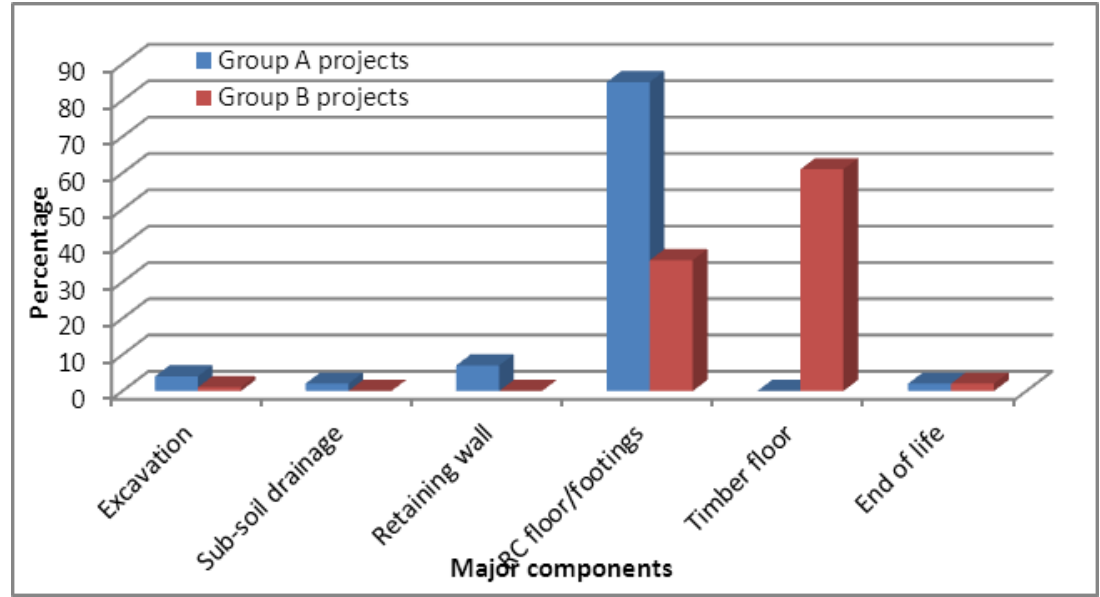

Figure 4: GHG emissions by major components for both groups

In Table 5 the floor structure is responsible for approximately $80 \mathrm{kgCO} 2-\mathrm{e} / \mathrm{m}^{2}$ and $40 \mathrm{kgCO} 2-\mathrm{e} / \mathrm{m}^{2}$ for GFA respectively for concrete and timber options. This means that the concrete option emits approximately twice as much GHG than the timber option. Similarly, when presenting GHG emissions using BF, the floor structure contributes $122 \mathrm{kgCO}_{2-\mathrm{e}} / \mathrm{m}^{2}$ and $48 \mathrm{kgCO} 2 \mathrm{e} / \mathrm{m}^{2}$ respectively for the concrete and timber options. From these calculations, the concrete slab construction has emitted 2.5 times more GHG than the suspended timber floor construction. 
This indicates that reinforced concrete tends to be more polluting than timber oriented construction methods, albeit that this situation could be improved by using low emission cements in the concrete option.

The ancillary work (including cut and fill excavation, subsoil drainage and retaining wall) of the concrete option generates a total of $13 \%$ of the total GHG emission as opposed to only $1 \%$ emission due to excavation for concrete pad footings in the suspended timber floor option (refer to Figure 4). It can be seen that the timber floor option poses a more environmentally friendly construction approach with reduced GHG emissions and less disturbance to the natural topography. In a similar situation, the end of life disposal of demolition waste contributes negligibly, with about $2 \%$ of GHG emissions for both options.

\section{Statistical analysis: t-test and dummy variables}

In order to understand whether there may be significant differences between the results of the timber and concrete projects, statistical analysis was conducted using a two-sample t-test of unequal variances and dummy variables in regression analysis. These were performed for both cumulative energy demand and GHG emissions on the building footprint (BF) only as this was considered the most appropriate unit to provide insight into the reliability of the findings. The purpose of the t-test was to make inferences about possible differences in the parameters of the two groups, while the dummy variables test analyses the relationship between variables. The results for the t-test and dummy variables are summarized in Tables 6 and 7.

Table 6: Summary of two-sample t-test for differences by construction methods

\begin{tabular}{|l|c|c|}
\hline \multicolumn{1}{|c|}{ Results } & Energy & GHG \\
\hline t Statistic & 7.33 & 7.44 \\
\hline$p$-Value & $9.09 \mathrm{E}-06$ & $7.74 \mathrm{E}-06$ \\
\hline Critical value & \pm 2.18 & \pm 2.18 \\
\hline Significance & Yes & Yes \\
\hline
\end{tabular}

The mean hypothesis test was undertaken using a two-tailed test at a 5\% level of significance (i.e. $\alpha=0.05)$. According to the results in Table 6 , all the $t$ Statistics were much higher than the critical value of \pm 2.18 and all the $p$-values were much less than 0.05 . In such cases, the null hypothesis can be rejected. Therefore, it is concluded that, based on the t-test results, there is evidence of significant differences in the samples of the two competing construction methods for both cumulative energy demand and GHG emissions. This statistically supports the previously reported finding that suspended timber floor construction results in significantly less cumulative energy demand and emits less GHG than the concrete construction method.

The study was further analysed using a dummy variable in regression analysis to analyse the effect of independent variables on cumulative energy demand and GHG emissions. These independent variables focused on $\mathrm{BF}$ for respective construction methods (i.e. concrete raft slab and suspended timber floor) as dummy variables. The test set the suspended timber floor construction method as the dummy and takes on a value of 1,0 otherwise (i.e. concrete raft slab method). The model was of the form:

$$
\begin{aligned}
& y=\beta_{0}+\beta_{1} x_{1}+\beta_{2} x_{2}+\varepsilon \\
& \text { Where } \quad y \quad=\text { cumulative energy demand or GHG emissions } \\
& \beta_{0}=\mathrm{y} \text {-intercept } \\
& \beta_{1}=\text { slope of } \mathrm{y} \text { with variable } \mathrm{x}_{1} \\
& \beta_{2}=\text { slope of } \mathrm{y} \text { with variable } \mathrm{x}_{2} \\
& \mathrm{x}_{1}=\mathrm{BF}\left(\mathrm{m}_{2}\right) \\
& \left.\mathrm{x}_{2}=\text { Construction methods (Timber }=1\right) \\
& \varepsilon=\text { random error }
\end{aligned}
$$


The results are summarized in Table 7. With the t Statistic for the line slope for BF and construction method, and the $p$-values less than 0.05 , each of two variables are making a significant contribution to the model, with a significance of 0.05 .

Table 7: Summary of results for dummy variable in regression analysis

\begin{tabular}{|l|c|c|}
\hline \multicolumn{1}{|c|}{ Results } & Cumulative Energy Demand & GHG Emission \\
\hline Multiple R & 0.92 & 0.93 \\
\hline R Square & 0.86 & 0.87 \\
\hline Adjusted R Square & 0.84 & 0.86 \\
\hline Standard Error & 46178.38 & 4734.09 \\
\hline Observations & 24 & 24 \\
\hline Coefficients & & 4782.7 \\
Intercept & 61779.4 & 120.9 \\
BF & 1058.9 & -16921.7 \\
Construction methods (Timber=1) & -154780.7 & 0.95 \\
\hline t Statistic & & 5.09 \\
Intercept & 1.26 & -8.08 \\
BF (m ${ }^{2}$ ) & 4.58 & 0.35 \\
Construction methods (Timber=1) & -7.57 & 0.00005 \\
\hline$p$-Value & & $7.05 \mathrm{E}-08$ \\
Intercept & 0.22 & 0.0002 \\
BF (m ${ }^{2}$ Construction methods (Timber=1) & $1.95 \mathrm{E}-07$ & \\
\hline
\end{tabular}

In the table, the adjusted $\mathrm{R}^{2}=0.92$ and 0.93 for cumulative energy demand and GHG emissions respectively, which implies that there is a strong fit of the model to the data. The high $\mathrm{R}^{2}$ values imply that $86 \%$ and $87 \%$ of the sample variation in cumulative energy demand and GHG emissions respectively can be explained by variation in the BF and construction method.

These results imply that there is a significant relationship between the independent variables (BF and construction method) and dependent variable (energy and GHG emission). The regression models to be fitted are:

Cumulative energy demand:

$$
\mathrm{y}=61779.4+1058.9 \mathrm{x}_{1}-154780.7 \mathrm{x}_{2}
$$

GHG emissions:

$$
\mathrm{y}=4782.7+120.9 \mathrm{x}_{1}-16921.7 \mathrm{x}_{2}
$$

When applying the model and holding the construction method constant, for each increase of $1 \mathrm{~m}^{2}$ in building footprint, the average energy demand is predicted to increase by $1,059 \mathrm{MJ}$. Similarly, for holding constant the building footprint, the use of suspended timber floor is predicted to reduce average energy demand by $154,781 \mathrm{MJ}$. In the same way for an increase of $1 \mathrm{~m}^{2}$ in building footprint, the GHG emission will increase by $121 \mathrm{kgCO}_{2-\mathrm{e}}$ and the use of suspended timber floor will decrease GHG emission by about $16,922 \mathrm{kgCO}_{2-\mathrm{e}}$.

\section{Conclusions}

In terms of cumulative energy demand, suspended timber floors consumed approximately 2.1 and 2.7 times less energy for GFA and BF, compared to concrete raft slabs. For GHG emissions, suspended timber floors exhibited even better performance. GHG emissions per GFA and BF in Group B were approximately 2.3 and 2.9 times (respectively) less than Group A. The results apply to sites ranging in slope from 5-15 degrees for concrete and 6-16 degrees for timber. The results also pertain to clay soil types. In focusing purely on the floor construction, and excluding end of life and ancillary construction required for concrete raft slabs, suspended 
timber floor construction has demonstrated a much lower result in both cumulative energy demand and GHG emissions.

The study used traditional Portland cement. In dissecting the results, it is apparent that concrete as a material must work towards lowering its embodied energy and GHG emissions relative to timber, in order to improve its environmental credentials. This is most apparent when considering the small quantity of concrete used in the timber floor for pad footings, yet it is a large contribution to GHG emissions with 36\%. With further focus on concrete slab construction, there is also the potential to consider ways of reducing the environmental impact of ancillary construction such as retaining walls, associated site drainage and cut and fill excavation.

While the data clearly indicates that suspended timber floors use less cumulative energy and emit less GHG than concrete floors, it is also notable that the values for cumulative energy and GHG are somewhat more constant for timber than concrete for different site slopes, as well. It is considered that this is likely the case, because suspended timber floors touch the ground in limited locations irrespective of site slope. There is a natural tendency to increase post spacing layouts as site slope increases. Subsequently, posts can be easily lengthened to deal with increased site slope while having relatively little impact on material use and by virtue of this, little variation in impact on embodied energy and GHG emissions.

A limitation of the study is that it does not take into account the potential benefit of thermal mass. Nor does it take into account the potential benefit of lightweight and well-ventilated open subfloor construction in hot climates. Future research should quantify this using a purposive sampling methodology with the use of real data and blended with computer modelling. It should consider the impact of thermal mass both on houses that are designed with passive solar features but equally with more random designs, as would typically occur in many instances where sustainability is not the major priority driving land and housing development.

\section{References}

Blengini, G.A. and Di Carlo, T., 2010. The Changing Role of Life Cycle Phases, Subsystems and Materials in The LCA of Low Energy Buildings. Energy and Buildings, 42(6), pp.869-80. doi: http://dx.doi.org/10.1016/i.enbuild.2009.12.009

Börjesson, P. and Gustavsson, L., 2000. Greenhouse Gas Balances in Building Construction: Wood Versus Concrete from Life-Cycle and Forest Land-Use Perspectives. Energy Policy, 28(9), pp.575-88. doi: http://dx.doi.org/10.1016/S0301-4215(00)00049-5

Buchanan, A.H. and Levine, S.B., 1999. Wood-Based Building Materials and Atmospheric Carbon Emissions. Environmental Science and Policy, 2(6), pp.427-37. doi: http://dx.doi.org/10.1016/S1462-9011(99)00038-6

Carre, A., 2011. A Comparative Life Cycle Assessment of Alternative Constructions of a Typical Australian House Design. Melbourne: FWPA.

Cole, R.J., 1998. Energy and Greenhouse Gas Emissions Associated with the Construction of Alternative Structural Systems. Building and Environment, 34, pp.335-45. doi: http://dx.doi.org/10.1016/S0360-1323(98)00020-1

Department of Climate Change and Energy Efficiency (DCCEE), 2010. National Greenhouse Accounts (NGA) Factors. Canberra: Department of Climate Change and Energy Efficiency.

Department of the Environment and Heritage (DEH), 2006a. ESD Design Guide for Australian Government Buildings, 2nd ed. Canberra: DEH Australian Greenhouse Office.

Department of the Environment and Heritage (DEH), 2006b. AGO Factors and Methods Workbook. Canberra: DEH Australian Greenhouse Office.

Ding, G.K.C., 2008. Sustainable Construction - The Role of Environmental Assessment Tools. Journal of Environmental Management, 86(3), pp.451-64. doi: http://dx.doi.org/10.1016/j.jenvman.2006.12.025

Ding, G. and Forsythe, P., 2013. Sustainable Construction: Life Cycle Energy Analysis of Construction on Sloping Sites for Residential Buildings. Construction Management and Economics, 31(3), pp.254-65. doi: http://dx.doi.org/10.1080/01446193.2012.761716

FWPA, 2010. Timber Service Life Design. Victoria: Forest Wood Products Australia. 
Gerilla, G.P., Teknomo, K. and Hokao, K., 2007. An Environmental Assessment of Wood and Steel Reinforced Concrete Housing Construction. Building and Environment, 42(7), pp.2778-784. doi: http://dx.doi.org/10.1016/j.buildenv.2006.07.021

Glover, J., White, D.O. and Langrish, T.A., 2002. Wood Versus Concrete and Steel in House Construction: A Life Cycle Assessment. Journal of Forestry, 100(8), pp.34-41.

Goggins, J., Keane, T. and Kelly, A., 2010. The Assessment of Embodied Energy in Typical Reinforced Concrete Building Structures in Ireland. Energy and Buildings, 42(5), pp.735-44. doi: http://dx.doi.org/10.1016/i.enbuild.2009.11.013

Gustavsson, L. and Sathre, R., 2006. Variability in energy and carbon dioxide balances of wood and concrete building materials. Building and Environment, 41(7), pp.940-51. doi: http://dx.doi.org/10.1016/j.buildenv.2005.04.008

International Standards Organisation, 2006. ISO 14040: Environmental Management - Life Cycle Assessment - Principles and Framework. Geneva: ISO.

IPCC, 2006. IPCC Guidelines for National Greenhouse Gas Inventories. Vol. 2 of General Guidance and Reporting. Kanagawa: Intergovernmental Panel on Climate Change.

Kauppi, P. and Sedjo, R., 2001. Technological and Economic Potential of Options to Enhance, Maintain, and Manage Biological Carbon Reservoirs and Geo-engineering. Working Group III Report, Ch. 4, pp.301-43. Geneva: IPCC.

Khasreen, M.M., Banfill, P.F.G. and Menzies, G.F., 2009. Life-cycle Assessment and the Environmental Impact of Buildings: A Review. Sustainability, 1, pp.674-701. doi: http://dx.doi.org/10.3390/su1030674

Li, X., Zhu, Y. and Zhang, Z., 2010. An LCA-based Environmental Impact Assessment Model for Construction Processes. Building and Environment, 45(3), pp.766-75. doi: http://dx.doi.org/10.1016/j.buildenv.2009.08.010

Lippke, B., Wilson, J., Perez-Garcia, J., Bowyer, J. and Meil, J., 2004. CORRIM: Life-cycle Environmental Performance of Renewable Building Materials. Forest Products Journal, 54(6), pp.8-19.

López-Mesa, B., Pitarch, Á., Tomás, A. and Gallego, T., 2009. Comparison of Environmental Impacts of Building Structures with in-situ Cast Floors and with Precast Concrete Floors. Building and Environment. 44(4), pp.699-712. doi: http://dx.doi.org/10.1016/j.buildenv.2008.05.017

Mahapatra, K., and Gustavsson, L., 2008. Multi-storey Timber Buildings: Breaking Industry Path Dependency. Building Research and Information, 36(6), pp.638-48. doi: http://dx.doi.org/10.1080/09613210802386123

Metz, B., 2007. Climate Change 2007-Mitigation of Climate Change. Contribution of Working Group III to the Fourth Assessment Report of the IPCC. In: B. Metz, O.R. Davidson, P.R. Bosch, R. Dave, L.A. Meyer eds. Cambridge, United Kingdom: Cambridge University Press.

Perez-Garcia, J., Lippke, B., Briggs, D., Wilson, J.B., Bowyer, J. and Meil, J., 2005. The Environmental Performance of Renewable Building Materials in the Context of Residential Construction. Wood and Fiber Science, 37, pp.3-17.

Puettmann, M.E. and Wilson, J.B., 2005. Life-cycle Analysis of Wood Products: Cradle-to-gate LCI of Residential Wood Building Materials. Wood and Fiber Science, 37, pp.18-29.

Sartori, I. and Hestnes, A.G., 2007. Energy use in the Life Cycle of Conventional and Low-energy Buildings: A Review Article. Energy and Buildings, 39(3), pp.249-57. doi: http://dx.doi.org/10.1016/j.enbuild.2006.07.001

Sathre, R. and O'Connor, J., 2010. Meta-analysis of Greenhouse Gas Displacement Factors of Wood Product Substitution. Environmental Science and Policy, 13(2), pp.104-14. doi: http://dx.doi.org/10.1016/j.envsci.2009.12.005

Siew, R.J.Y., Balatbat, M.C.A. and Carmichael, D.G., 2013. A Review of Building/Infrastructure Sustainability Reporting Tools (SRTs). Smart and Sustainable Built Environment, 2(2), pp.106-39. doi: http://dx.doi.org/10.1108/SASBE-03-2013-0010

Standards Australia, 2011. AS2870: Residential Slabs and Footings. Sydney: Standards Australia.

Stern, N., 2007. The Economics of Climate Change: the Stern Review. Cambridge: Cambridge University Press. doi: http://dx.doi.org/10.1017/CBO9780511817434

Thormark, C., 2002. A Low Energy Building in a Life Cycle - its Embodied Energy, Energy Need for Operation and Recycling Potential. Building and Environment, 37(4), pp.429-35. doi: http://dx.doi.org/10.1016/S03601323(01)00033-6

Worrell, E., Price, L., Martin, N., Hendriks, C. and Meida, L.O., 2001. Carbon Dioxide Emissions from the Global Cement Industry. Annual Review of Energy and the Environment, 26(1), pp.303-29. doi: http://dx.doi.org/10.1146/annurev.energy.26.1.303

Upton, B., Miner, R., Spinney, M. and Heath, L.S., 2008. The Greenhouse Gas and Energy Impacts of Using Wood Instead of Alternatives in Residential Construction in the United States. Biomass and Bioenergy, 32(1), pp.1-10. doi: http://dx.doi.org/10.1016/j.biombioe.2007.07.001

Ximenes, F., Robinson, M. and Wright, B. and Forest and Wood Products Research and Development Corporation (Australia) and Cooperative Research Centre for Greenhouse Accounting, 2006. Forests, Wood and Australia's Carbon Balance. Melbourne: Forest and Wood Products Research and Development Corporation. 